\title{
PERILAKU REMAJA PUTRI DALAM PELAKSANAAN KEBERSIHAN GENETALIA SAAT MENSTRUASI DI DS.KRAYAN BAHAGIA
}

\author{
Zubaidah Zubaidah \\ Program Studi Diploma Tiga Keperawatan Stikes Intan Martapura, Indonesia \\ Email : buyungzubaidah@gmail.com
}

\begin{abstract}
ABSTRAK
Menstruasi merupakan suatu fase yang dialami oleh setiap remaja putri yang terjadi ketika mulai memasuki masa remaja. Kondisi ini berlangsung 3-7 hari dan rutin terjadi setiap bulan. Ketika memasuki fase menstruasi terkadang remaja belum mendapatkan informasi yang baik mengenai cara merawat organ reproduksi dengan baik. Penelitian ini dilakukan dengan tujuan untuk mengetahui perilaku remaja putri dalam pelaksanaan kebersihan genetalia pada saat menstruasi. Penelitian bersifat deskriftif untuk menilai perilaku remaja putri dalam pelaksaan kebersihan genetalia pada saat menstruasi. Pengambilan sampel dilakukan dengan cara purposive sampling dengan besar sampel sebanyak 50 responden dengan menggunakan teknik pengumpulan data berupa kuesioner. Hasil dari penelitian ini menunjukkan perilaku remaja putri dalam pelaksanaan kebersihan genetalia pada saat menstruasi sangat kurang, dimana hanya 14 responden yang menjaga kebersihan genetalia dengan baik. Berdasarkan hasil penelitian yang telah didapat, perlumya peningkatan pengetahuan remaja putri mengenai pelaksanaan kebersihan genetalia, agar remaja putri untuk mampu merubah perilaku kearah perilaku bersih sehat yang tentunya akan meningkatkan kualitas kesehatan remaja tersebut.
\end{abstract}

\section{Kata Kunci : perilaku, kebersihan genetalia, Remaja Putri}

\section{ABSTRACT}

Menstruation is a phase experienced by every young woman that occurs when she enters adolescence. This condition lasts 3-7 days and regularly occurs every month. When entering the menstrual phase, teenagers sometimes do not get good information about how to properly care for their reproductive organs. This study was conducted with the aim of knowing the behavior of adolescent girls in the implementation of genital hygiene during menstruation. This research is descriptive in nature to assess the behavior of adolescent girls in the implementation of genital hygiene during menstruation. Sampling was done by purposive sampling with a sample size of 50 respondents using data collection techniques in the form of questionnaires. The results of this study indicate that the behavior of adolescent girls in the implementation of genital hygiene during menstruation is very lacking, where only 14 respondents maintain good genital hygiene. Based on the results of the research that has been obtained, it is necessary to increase the knowledge of young women regarding the implementation of genital hygiene, so that young women are able to change their behavior towards clean and healthy behavior which will certainly improve the quality of their health.

Keywords : Behavior,genetal hygiene, adolescent girls

Cite this as : $\quad$ Zubaidah, Z. (2021). Perilaku Remaja Putri dalam Pelaksanaan Kebersihan Genetalia Saat Menstruasi di Desa Krayan Bahagia. Jurnal Ilmu Kesehatan Insan Sehat, 9(1), 1-4.

\section{PENDAHULUAN}

Fase mensturasi adalah suatu proses keluar darah melalui vagina yang berasal dari rahim karena terjadinya peluruhan lapisan dinding rahim. Siklus menstuasi terjadi tiap bulan dan mulai terjadi saat usia 12-15 tahun, namun pada beberapa anak mengalami menstruasi lebih awal dari rentang usia seharusnya yang dipengaruhi berbagai faktor salah satunya faktor hormonal. Periode menstruasi pada remaja dapat terjadi antara 3-7 hari (Errol, 2015).

Kebersihan genetalia saat menstruasi sangat penting karena saat haid genetalia mengeluarkan darah, sehingga genetalia akan menjadi basah dan lembab. Hal ini akan menyebabkan bakteri berkembang biak pada area genetalia dan menyebabkan infeksi seperti keputihan, gatal-gatal di area vagina.

Perawatan genetalia oleh remaja putri saat mengalami fase menstruasi sangat penting dilakukan. Perawatan yang dilakukan yaitu membersihkan pada area vagina dari arah depan ke belakang, menggunakan air cebok yang bersih, menggunakan pembalut serta mengetahui cara memakainya, sering mengganti pembalut, menggunakan pakaian dalam yang bersih dan 
mudah menyerap keringat, dan menjaga kebersihan area genital selama proses menstruasi terjadi. Kesadaran diri untuk menjaga kebersihan area genital harus ditanamkan sejak dini dan perlunya pengetahuan akan pentingnya merawat area tersebut (Nadesul, 2012).

Banyak remaja putri yang tidak melakukan perawatan genetalia. Perilaku ini disebabkan oleh kurangnya pengetahuan sehingga perilaku remaja putri tidak melaksanakan serta menjaga kebersihan pada saat menstruasi. Malas dalam mengganti pembalut serta celana dalam, menjadi hal yang sering tidak diperhatikan oleh para remaja putri (Nirwana, 2014).

Secara umum, dampak yang sering terjadi akibat kurang menjaga kebersihan genetalia saat periode menstruasi akan mengakibatkan area genetalia mengalami infeksi, gatal-gatal, kemerahan pada area sekitar, keputihan, timbulnya bau yang tidak sedap. Akibat lainnya yang muncul jika tidak menjaga kebersihan bagian genetalia pada saat menstruasi, remaja berisiko mengalami demam, terjadi peradangan pada area vagina, mengalami keputihan, dan bagian bawah perut akan terasa sakit serta terasa panas (Yuni, 2015). Apabila terus menerus terjadi dan hal ini berlangsung lama, akan menimbulkan ISR yang tentunya menjadi risiko besar terkena kanker pada leher rahim, risiko terjadinya kehamilan diluar kandungan, saluran telur terjadi penyempitan, serta endomertiosis (Irianto, 2015).

Dampak-dampak negatif yang tidak diperhatikan dan terus dibiarkan akan memicu akibat lain yang lebih serius seperti terjadinya kanker serviks. Kanker tersebut disebabkan oleh Human Papilloma Virus (HPV) yang berkembang biak di dalam organ kelamin wanita. Hal ini dapat terjadi karena area sekitar kelamin yang lembab serta kurangnya kebersihan pada organ kelamin. Sejalan dengan penelitian (Progestian, 2009 dalam Rahmatika, 2010) yang menyatakan virus HPV hidup dan berkembangbiak di organ genetalia yang kondisinya lembap, yaitu di dalam cairan vagina yang biasanya terjadi pada perempuan yang mengalami keputihan.

Upaya yang dapat dilakukan untuk menghindari berbagai dampak negatif tersebut yaitu dengan memperhatikan penggunaan pembalut dengan baik dengan tidak memakai lebih dari enam jam. Pembalut harus sering di ganti karena dalam rentang waktu enam jam pembalut akan dipenuhi oleh darah menstruasi (Haryono, 2016).

Data World Health Organization (WHO) dalam Suryandi dan Rufaida (2013) mengenai angka penyakit keputihan yang sering dialami remaja putri cukup tinggi. Hal ini di buktikan dengan data yang diperoleh terdapat $60 \%$ remaja berusia 15-22 tahun yang menyatakan mengalami keputihan dan $40 \%$ terjadi pada wanita berusia 23-45 tahun. Keputihan dapat mengakibatkan dampak yang buruk bagi kesehatan organ genetalia jika terus dibiarkan. Penelitian Wulandari (2015) menyatakan bahwa $75 \%$ wanita mengalami penyakit keputihan minimal satu kali dalam hidupnya, yang mana $50 \%$ terjadi pada usia remaja dan $35 \%$ terjadi ketika berada pada usia subur (WUS). Penyakit kanker serviks yang sering terjadi pada wanita di Indonesia kebanyakan di awali dengan adanya keputihan parah yang dialami terus menerus.

Hasil wawancara dengan 10 responden yang didapatkan di Ds,Krayan Bahagia Kabupaten Paser Tahun 2020, 8 dari 10 siswa mengatakan tidak tau cara membersihkan genetalia yang benar saat menstruasi. Mereka hanya mencuci biasa saja dan jarang mengganti pembalut saat menstruasi. Hal ini menunjukkan bahwa perilaku merawat kebersihan genitalia memang sangat kurang. Berdasarkan data-data yang diperoleh, beserta dampak yang ditimbulkan akibat kurangnya pengetahuan remaja putri mengenai kebersihan genital, maka peneliti tertarik untuk mengangkat fenomena ini.

\section{METODE}

Penelitian ini menggunakan metode penelitian deskriftif kuantitatif dan pengambilan data responden dengan melakukan penyebaran kuesioner. Kuesioner terlebih dahulu disusun dan dilakukan uji validitas yang kemudian menjadi instrument penelitian. Pada penelitian ini populasi yang diambil adalah remaja putri yang sudah menstruasi di Ds.Krayan Bahagia Kab.Paser sebanyak 50 orang. Metode pengambilan sampel yang digunakan dalam penelitian ini adalah Random Sampling, yaitu proses pengambilan data dengan sistem acak. Didalam penelitian berdasarkan formulasi yaitu sebanyak 50 responden. data diambil dengan kuesioner melalui via google from dan dianalis melalui distribusi dan presentase.

\section{HASIL}

Tabel 1 : Distribusi Frekuensi Karakteristik Umum Responden Berdasarkan Umur

\begin{tabular}{ccc}
\hline Umur & $\mathbf{N}$ & $\mathbf{\%}$ \\
\hline $15-16$ & 24 & 48 \\
\hline $17-18$ & 26 & 52 \\
\hline Total & $\mathbf{5 0}$ & $\mathbf{1 0 0}$ \\
\hline
\end{tabular}

Berdasarkan tabel 4.1 dapat dilihat bahwa umur remaja putri yang menjadi responden terbanyak adalah umur 17-18 tahun yaitu sebanyak sebanyak 26 responden $(52 \%)$

Tabel 2: Distribusi frekuensi responden perilaku remaja putri dalam pelaksanaan kebersihan genetalia pada saat menstruasi

\begin{tabular}{lll}
\hline Perilaku & $\mathbf{N}$ & $\mathbf{\%}$ \\
\hline Baik & 14 & 28 \\
\hline Kurang & 36 & 72 \\
\hline Total & $\mathbf{5 0}$ & $\mathbf{1 0 0}$ \\
\hline
\end{tabular}


Berdasarkan tabel 2 dapat dilihat bahwa terdapat 14 responden $(28 \%)$ responden yang perilaku baik melakukan kebersihan genetalia pada saat menstruasi dan sebanyak 36 responden (72\%) yang berperilaku kurang.

Tabel 3: Tabulasi silang umur responden dengan perilaku remaja putri tentang pelaksanaan kebersihan genetalia pada saat menstruasi.

\begin{tabular}{|c|c|c|c|}
\hline \multirow[b]{2}{*}{ Umur } & \multicolumn{2}{|c|}{ Perilaku } & \multirow[b]{2}{*}{ Total } \\
\hline & Baik & Kurang & \\
\hline \multirow[t]{2}{*}{$15-16$} & 6 & 18 & 24 \\
\hline & $12 \%$ & $36 \%$ & $48 \%$ \\
\hline \multirow[t]{2}{*}{$17-18$} & 8 & 18 & 26 \\
\hline & $16 \%$ & $36 \%$ & $52 \%$ \\
\hline \multirow[t]{2}{*}{ Total } & 14 & 36 & 50 \\
\hline & $28 \%$ & $72 \%$ & $100 \%$ \\
\hline
\end{tabular}

Berdasarkan tabel 3 dapat dilihat pada tabulasi silang antara variabel tingkat usia dan perilaku remaja putri dalam pelaksanaan kebersihan genetalia pada saat menstruasi diperoleh hasil mayoritas positif,responden dengan usia 17-18 sebanyak 26 (100\%)

\section{PEMBAHASAN}

Hasil penelitian menunjukkan bahwa remaja putri banyak yang kurang melakukan kebersihan genetalia sebanyak 36 responden (72\%). Sesuai dengan teori yang dinyatakan oleh Notoatmojo (2012), faktor yang mempengaruhi perilaku yaitu faktor pemungkin dan faktor pendorong. Penelitian ini membuktikan bahwa perilaku yang terbentuk dengan adanya pengetahuan yang baik maka akan menghasilkan perilaku yang lebih baik dibandingkan perilaku yang tidak didasari pengetahuan. Pelaksanan kebersihan genetalia sangat penting bagi usia remaja, yang jarang dilakukan remaja saat menstruasi adalah malas mengganti pembalut dan celana dalam.

Berdasarkan hasil penelitian tentang perilaku remaja putri mencuci tangan dan cebok saat menstruasi diperoleh rata-rata responden menjawab yaitu 41 responden (82\%) kategori baik dan sebanyak 17 (34\%) responden yang menjawab kategori tidak melakukan sebanyak. Aktivitas membersihkan kedua tangan dengan sabun sebelum dan sesudah alat kelamin dibersihkan dengan tujuan menghindari masuknya bakteri atau kuman kedalam mulut karena bagian tubuh terutama tangan sering digunakan untuk aktivitas makan dan minum.

Berdasarkan penelitian dari MINAR A.J (2016) mengenai perilaku higienis saat menstruasi pada siswi sekolah menengah negeri didapatkan responden yang memiliki perilaku baik atau melakukan sebanyak 242 responden menjawab benar perlu mencuci tangan terlebih dahulu sebelum dan sesudah menyentuh vagina. Cuci tangan merupakan aktifitas penting yang harus selalu diterapkan untuk mencegah terjadinya infeksi terutama pada bagian genetalia

http://jurnalstikesintanmartapura.com/index.php/jikis
Berdasarkan hasil penelitian tentang perilaku menjaga vagina agar tidak menggunakan bedak atau sabun pada vagina saat menstruasi diperoleh yang menjawab kategori baik sebanyak 37 responden (74\%) dan yang 38 responden (76\%) menjawab kategori tidak. Berbagai alasan penggunaan sabun yang didapat bahwa remaja putri banyak yang menggunakan sabun khusus organ genetalia ketika menstruasi agar organ genetalia tidak berbau. Penggunaan sabun oleh remaja putri dilakukan setiap hari karena merasa organ kewanitaan lebih bersih jika dibersihkan dengan sabun daripada hanya menggunakan air bersih saja

Berdasarkan penelitian Imoratul fitriah (2014) yang menyebutkan bahwa 92,3\% responden membersihkan alat kelamin hanya dengan air bersih. Bertentangan dengan penelitian ini yang mendapatkan hasil sebagian besar responden menyatakan adanya penggunaan sabun ketika membersihkan alat kelamin sebanyak 38 (76\%). Penggunaan air bersih hangat untuk membersihkan area genital penting di lakukan tidak hanya saat mengalami menstruasi, tetapi harus dilakukan setiap saat terutama setelah buang air kecil dan besar dengan tujuan area sekitar genital tetap terjaga kelembabannya. Pada vagina terdapat kuman doderlin yang memiliki kemampuan memproduksi asam dengan tujuan mencegah masuknya bakteri ke dalam organ vagina dan menghindarkan terjadinya infeksi pada area tersebut sehingga penggunaan sabun tidak direkomendasikan.

Berdasarkan hasil penelitian perilaku remaja putri tidak sembarangan menggunakan cairan dan penggunaan pembalut diperoleh yang menjawab kategori baik sebanyak 33 responden (66\%) sedangkan yang menjawab kategori kurang sebanyak 38 responden (76\%). Hasil menunjukan bahwa setelah buang air kecil dan buang air besar terutama saat sedang menstruasi, remaja putri tidak segera mengganti pembalut dan juga ketika darah menstruasi hanya keluar sedikit mereka tidak menggunakan pembalut. Penggantian pembalut 
yang dilakukan remaja biasanya pada sore hari berbarengan dengan mandi sore.

Ketika mengalami periode menstruasi remaja putri seharusnya menggunakan pembalut bersih dan menjaga kebersihannya. Saat menstruasi sangat dianjurkan untuk sering-sering mengganti pembalut karena pembalut yang berisi darah menstruasi tentu menyimpan bakteri, terlebih jika dalam waktu lama dibiarkan tanpa diganti yang baru. Permukaan pembalut yang terkena segumpal darah walaupun sedikit sangat perlu diganti karena akan berdampak pada pertumbuhan jamur maupun bakteri yang mengakibatkan terjadinya berbagai gangguan pada area vagina seperti bau, keputihan serta infeksi lainnya (Depkes, 2010).

Sejalan dengan penelitian dan pernyataan dari imoratul fitriyah (2014) yang mendapatkan hasil responden remaja mengganti celana dalam hanya 2 kali (71\%) dan $(81 \%)$ remaja mengganti celana dalam saat terkena darah menstruasi. Penggantian celana dalam minimal 2 kali dalam sehari secara rutin, dilakukan dengan upaya menjaga kelembapan area genital. Ketika kondisi kelembapan berlebihan, area genital berisiko terinfeksi bakteri yang lama-lama akan semakin banyak tumbuh dan memicu timbulnya penyakit pada area genital.

\section{KESIMPULAN}

1. Berdasarkan hasil penelitian didapatkan hasil perilaku remaja putri tentang pelaksanaan kebersihan genetalia pada saat menstruasi di Ds.Krayan bahagia kab.paser yang menjawab kategori kurang sebanyak 26 responden $(52 \%)$

2. Berdasarkan hasil penelitian perilaku remaja putri tentang pelaksanaan kebersihan genetalia pada saat menstruasi dengan melakukan mencuci tangan sebelum menyentuh vagina dan cebok yaitu mayoritas berkategori baik sebanyak 41 responden $(82 \%)$

3. Berdasarkan hasil penelitian perilaku remaja putri tentang pelaksanaan kebersihan genetalia pada saat menstruasi dengan melakukan menjaga vagina agar tetap kering dan tidak mnggunakan bedak pada
Zubaidah Zubaidah, Perilaku Remaja Putri vagina yaitu mayoritas berkategori baik sebanyak 37 responden $(74 \%)$

4. Berdasarkan hasil penelitian perilaku remaja putri tentang pelaksanaan kebersihan genetalia pada saat menstruasi dengan melakukan tidak sembarangan menggunakan cairan dan mengganti pembalut yaitu mayoritas berkategori baik sebanyak 33 responden $(66 \%)$

\section{SARAN}

Hasil penelitian yang telah didapatkan, digunakan sebagai penunjang informasi dan masukan dalam memberikan layanan asuhan keperawatan secara komprehensif dengan memperhatikan aspek pengetahuan, sikap dan perilaku sehingga dapat menambah referensi untuk mengembangkan ilmu keperawatan dan menjadi bahan masukan tenaga keperawatan untuk meningkatkan kinerja layanan secara professional dan optimaluntuk meningkatkan derajat kesehatan masyarakat. Perlunya pengembangan penelitian lebih lanjut dengan memberikan intervensi keperawatan yang komprehensif sebagai upaya mengatasi permasalahan perilaku kebersihan organ genital remaja putri di Indonesia.

\section{DARTAR PUSTAKA}

Errol, dkk. 2015. Menstruasi keluarnya darah dari dalam rahim. Jakarta: PT.Agro Media Pustaka.

Haryono, 2016. Kebersihan genetalia remaja putri. Yogyakarta, Aura Media.

Nirwana, 2014. Perilaku remaja putri. Jakarta, Trans Infomedia.

Minar A.J (2016)dengan judul Perilaku hygienis saat menstruasi pada siswi sekolah menengah negeri di balige.

Nadesul, 2012. Menjaga kebersihan genetalia.

Yogyakarta: Rahpa Publishing.

Notoatmojo, 2012. Pendidikan dan ilmu perilaku. Jakarta:Rhineka Cipta.

Progestian, 2009. Perilaku yang tidak higienis pada saat menstruasi. Jakarta, Trans Infomedia.

Yuni, 2015. Buku suku personal hygiene. GEN.Yogyakarta:Nuha Medik. 